\title{
Effect of azolla as feed supplement on milk production of lactating buffaloes at Neemuch district Madhya Pradesh
}

\author{
Shilpi Kerketta ${ }^{1}$, SS Sarangdevot ${ }^{1}$, PS Naruka ${ }^{1}$, Shilpi Verma ${ }^{1}$, CP Pachauri ${ }^{1}$, AK Singh ${ }^{2}$, JP Singh $^{1}$ and SS Bhadauria $^{3}$
}

Received: 06 March 2020 / Accepted: 25 June 2020 / Published online: 10 September 2020

(C) Indian Dairy Association (India) 2020

\begin{abstract}
Azolla holds the promise of providing a sustainable feed for livestock. Azolla, a floating fern reported to be a very good source of protein, essential mineral elements and vitamins for livestock. The present study was undertaken to know effect of feeding azolla on milk production performance (milk yield, fat $\%$, SNF\%) of lactating buffaloes under field conditions. A total of 40 lactating buffaloes were selected and categorized into two groups each having 20 buffaloes. The animals in control group (T0) were fed on conventional ration of paddy straw, green fodder and concentrate mixture as per recommendation of NRC. In the treatment group (T1) $2 \mathrm{~kg}$ of fresh azolla was supplemented over conventional ration. The effect of fresh Azolla supplementation in lactating buffaloes was studied in an early lactation period of 90 days. The average milk yield $(\mathrm{kg} / \mathrm{d})$ was found significantly higher $(\mathrm{P}<0.05)$ in $\mathrm{T} 1(7.4 \pm 0.08)$ than $\mathrm{T} 0(6.5 \pm 0.13)$. On an average milk yield increase by $0.9 \mathrm{~L} /$ day over control group animals. These results showed that supplementing of azolla caused an increase in milk yield by $13.8 \%$. The average percentage of milk fat, milk protein, SNF showed no significant difference between two groups but the fat $\%$ was found higher in $\mathrm{T} 1$ as compared to $\mathrm{T} 0$. Peak milk yield was also found significantly $(\mathrm{P}<0.05)$ higher in azolla fed group than the control group. Thus, it can be concluded that azolla can serve as a potential alternative nutrient supplement for the lactating buffaloes for the improvement of productivity in
\end{abstract}

\footnotetext{
${ }^{1}$ KVK Neemuch, Madhya Pradesh, India

${ }^{2}$ Department of Animal Nutrition,FVAS, RGSC, BHU, India

${ }^{3} \mathrm{PS}$ to DES

A K Singh $(\bowtie)$

Department of Animal Nutrition, FVAS, RGSC, BHU, Varanasi, Uttar Pradesh 221 005, India

Email: vetabhi04@gmail.com
}

terms of milk specially where/when green fodder availability is scanty. However, further studies are needed for determining the replacement amount of azolla for concentrate to make it cost effective for farmers.

\section{Keywords: Azolla, Buffalo, Milk, Milk fat, Milk SNF}

India has huge and rich livestock population which play significant role in national economy. At present India is a leading country in milk production out of this majority of production i.e, $56 \%$ is being contributed by buffaloes. The milk production is not dependent on only one factors rather than several factors, one among them is decreasing feed and fodder for the supporting the growing livestock's population. There is acute shortage of feed and fodder for dairy animals due to lack of land availability for growing fodder for animals and high population density. Today shortage of dry fodder, green fodder and concentrate has been estimated to be $21 \%, 35.6 \%$ and $44 \%$, respectively (Kumar, 2018). To maintain continuous milk production it is essential to be provided with adequate feed and fodder, along with other supplement. Primary consideration on feed resources must be to identify the feed resources in ample supply to provide the bulk of a ration for the local herd and the supplements needed to balance the animal's nutrition. One among them is Azolla as a feed supplement which could be a good alternative for green fodder and concentrates to fulfill the nutrient requirement of animal.

Azolla is a free floating, rapidly growing aquatic fern on water surface forming symbiotic relationship with the cyanobacterium Anabaena azollae, which fixes atmospheric nitrogen. Azolla is rich incrude protein content which varies between 15.4 to $27.93 \%$ i.e 4 to 5 times more protein of excellent quality in comparison to hybrid napier and lucerne, respectively (Pillai et al. 2002). Along with this it is also good source of minerals (calcium, phosphorous, potassium, ferrous, copper, magnesium) and vitamins (vitamin A, vitamin B12, Beta Carotene). Azolla meal contains $25.78 \%$ crude protein, $15.71 \%$ crude fiber, $3.47 \%$ ether extract, $15.76 \%$ ash and $30.08 \%$ nitrogen free extract on the airdry basis (Basak et al. 2002). Azolla pinnata had high crude protein content and better mineralprofiling (Calcium, phosphorus and Potassium are $1.67 \%, 0.31 \%$ and $2.68 \%$ ) respectively (Bhatte et 
al. 2020). Azolla can act as a valuable green feed supplement for dairy cattle to improve productivity (Chatterjee et al. 2013). Due to easy cultivation, good nutritive value and high productivity it may be used as a beneficial fodder supplement as reported by various scholars (Prabina and Kumar, 2010). One hectare of azolla can produce $540-720 \mathrm{~kg}$ of protein per month. Various work on economics and nutritive value of azolla rich in protein and low in lignin content indicates that it has been one of the most economic and efficient feed substitutes for livestock which can be easily digested. Due to its beneficial characteristics Azolla is called "Green Gold" (Wagner, 1997). Keeping in view the above features of the supplement the objective of the present study was to evaluate the effect of Azolla as feed supplement on milk production performance of lactating buffaloes.

The present study was carried out at farmers field of various villages of Neemuch district (Madhya Pradesh, India). For trial a total of 20 locally available buffalo breeds having 2 nd to 5 th parity of early lactation stage were selected. The lactating buffaloes were divided into two groups of 10 buffaloes each. Treatment 1 ( $\mathrm{T} 0$ ) ( $\mathrm{n}=10)$ : Control group (Farmers' practices), no supplementation of Azolla as feed supplement. Treatment 2 (T1) $(n=10)$ : Supplementation of Azolla as feed supplement at rate of $2 \mathrm{~kg} /$ day/animal for 90 days. In control group (T0) animals were fed with wheat straw with market purchased concentrate mixture, whereas the treatment group (T1) was fed with same quantity of roughages and concentrate with supplementation of fresh green Azolla pinnata. The buffaloes were hand-milked twice daily morning and evening. Before commencement of the trial the milk yield of individual buffalo was noted as well as after commencement of the experiment the milk yield was recorded fortnightly for a period of 3 months. Along with this on each milk recording day the milk sample was subjected for the analysis of Fat $\%$ and SNF $\%$. The data was recorded for 90 days and the comparison was carried out for milk yield,fat percentage in

Table 1 Effect of azolla supplementation on milk yield and fat $\%$ in lactating buffaloes

\begin{tabular}{llc}
\hline & T0 & T1 \\
\hline $\begin{array}{l}\text { Milk yield } \\
\text { (L/day) }\end{array}$ & $6.5 \pm 0.13^{\mathrm{a}}$ & $7.4 \pm 0.08^{\mathrm{b}}$ \\
$\begin{array}{l}\text { Fat\% } \\
\text { Average }\end{array}$ & $5.81 \pm 0.20$ & $6.01 \pm 0.25$ \\
$\begin{array}{l}\text { increase in milk yield } \\
\% \text { increase in }\end{array}$ & - & 0.9 \\
$\begin{array}{l}\text { milk yield } \\
\% \text { increase in }\end{array}$ & - & 13.8 \\
$\begin{array}{l}\text { Milk fat } \\
\text { Total Milk }\end{array}$ & - & 0.2 \\
$\begin{array}{l}\text { Yield for } 90 \\
\text { days (L) }\end{array}$ & $585 \pm 0.53^{\mathrm{a}}$ & $666 \pm 0.58^{\mathrm{b}}$ \\
\hline
\end{tabular}

Means bearing different superscripts in a row differ significantly $(\mathrm{P}<0.05)$ between groups. The data were compiled and analyzed using Ttest (Snedecor and Cochran, 1994) with the help of SPSS package programme (SPSS 9.00 software for Windows, SPSS Inc., Chicago, IL).

For demonstration of the azolla unit a kuccha trench was made at farmers land. Before this a plain area was selected and then cleaned and leveled. A trench of area $3 \mathrm{~m} \mathrm{X} 1.5 \mathrm{~m} \mathrm{X} 0.2 \mathrm{~m} \mathrm{dug}$, further covered with silpaulin sheet to prevent draining of water into the earth. The size of the sheet was $0.5 \mathrm{~m}$ longer and wider than the pit and was secured by a layer of mud at the edges. Filtered fertile soil $10-15 \mathrm{~kg}$ uniformly spread over the silpaulin sheet. Cow dung slurry $2 \mathrm{~kg}$ along with super phosphate 20 gms mixed in 10 litre of water and poured into the pit. Pour water into the pit until a $10 \mathrm{~cm}$ space left from top. Finally add about $1 \mathrm{~kg}$ of fresh azolla culture on the surface of water, so that in 10-15 days azolla will multiply rapidly to fill the whole pond. As per requirement azolla is fed $1.5-2.0 \mathrm{~kg} / \mathrm{animal} /$ day and the investment in milk production can be minimized

Economics of Azolla production (Kuccha azolla pit)

Cost of silpaulin sheet

Rs. 340.00

Nylon Shady net (5 x 2 mt). @ Rs.30/-mt

Rs. 300.00

Azolla 2 kg@ Rs. 55/-kg

Rs. 110.00

Super phosphate240 gms@20g/month

Rs. 6.00

Total cost

Rs. 756.00

From the above data it is clear that the cost of construction a kuccha azolla pit is very easy and cheap. Here the cost of labour, and dung is excluded, as the farmer itself dug the pit without hiring the labour, using dung excreted by his own cow/ buffalo.Giving due consideration to the one-time cost of permanent structure and recurring expenses, the cost of Azolla production would be less than 65 paisa per $\mathrm{Kg}$.

The average milk yield $(\mathrm{kg} / \mathrm{d})$ over 6 fortnights was significantly higher $(\mathrm{P}<0.05)$ in T1 $(7.4 \pm 0.08)$ than T0 (6.5 \pm 0.13$)$. Similar trend was also found for fat $\%$ however the result was non significant i.e, $5.81 \pm 0.20$ and $6.01 \pm 0.25$ for $\mathrm{T} 0$ and $\mathrm{T} 1$ respectively. The result was in concordance with Chaterjee et al. (2013), performed trial in crossbred cattle and found significant increase in milk yield in control and azolla fed group cattle ( $7.14 \pm 0.08$ vs $6.42 \pm 0.13 \mathrm{~L} /$ day). Here the fat corrected milk followed increasing trend with $7.04 \pm 0.15$ (Control) and 7.92 \pm 0.09 (Azolla fed) groups. Further the milk yield showed increasing trend and it increased to $10.5 \mathrm{~L} /$ day from $8.8 \mathrm{~L} /$ day after 90 days of azolla feeding per day with conventional feed Mustard oilseed cake in lactating buffaloes (Singh et al. 2017; Meena et al. 2017). Hence the total milk yield for 90 days also have significant difference between control and treatment group i.e, $585 \pm 0.53 \mathrm{~L}$ and $666 \pm 0.58 \mathrm{~L}$ respectively. 
Average increase in milk yield recorded to be $0.9 \mathrm{~L} /$ day. Percent increase in milk yield found to be high $(13.8 \%)$, however percent increase in fat recorded to be very low $(0.2)$, indicating the azolla rich in protein and mineral content is helpful in enhancing milk yield but have little effect on fat $\%$. Bhatt et al (2020) concluded that Azolla pinnata feeding improves the feeding and resting behavior without affecting the overall performance ofcalves. Similarly, an average milk yield increase of $1.70 \mathrm{~L} /$ day was reported by Singh et al. (2017) in lactating buffaloes and tremendous increase in milk yield (19.32\%) was found. It was also supported by Mathur et al. (2013), with $20.96 \%$ and $16.90 \%$ increase in milk yield in cattle and buffalo respectively and by Rawat et al. (2015) and Gowda et al. (2015) in cross bred cattle. Fat \% when compared was also reported to be slightly increased i.e 4.3 to 4.7 in cattle and 6.2 to 6.7 in buffaloes. Due to increase in milk yield per day the overall milk production for observation period (90 days) was also found to be significantly $(\mathrm{P}<0.05)$ higher in azolla fed group as compared to control group (666 \pm 0.58 versus $585 \pm 0.53 \mathrm{~L})$.

\section{Conclusion}

From above study it can be concluded that azolla can serve as a potential alternative nutrient supplement for lactating buffaloes for the improvement of productivity in terms of milk as this is a good source of protein especially where/when green fodder availability is scanty. It enhances milk yield along with fat $\%$ in lactating buffaloes improving economic status of farmers. However, further studies are needed for determining the replacement amount of Azolla for concentrate to make it cost effective for farmers.

\section{References}

Basak B, Pramanik, AH, Rahman MS, Tarafdar SU, Roy BC (2002) Azolla (Azollapinnata) as a feed ingredient in broiler ration. Int J Poult Sci 1: $29-34$
Bhatt N, Chandra R, Kumar S, Singh K, Pratap N (2020) Nutritive Analysis of Azollapinnata and its Cultivation during Winter Season. Int J Curr Microbiol App Sci 9: 2012-2018

Bhatt N, Kumar S, Singh K, Chandra R, Kumar A (2020) Behavioural investigation of Sahiwal calves under Azollapinnata feeding in early morning hours during cold season. J Entomol Zool Stud 8: 310-313

Chatterjee A, Sharma P, Ghosh M.K, Mandal M, Roy PK (2013) Utilization of azolla microphylla as feed supplement for crossbred cattle. Int $\mathrm{J}$ Agric Food Sci Technol 4: 207-214

Gowda NKS, Manegar A, Verma S, Valleesha NC, Maya G, Pal DT, Suresh KP (2015). Azolla (Azolla pinnata) as a green feed supplement for dairy cattle-an on farm study. Anim Nutr Feed Technol 15: 283-287

Kumar R (2017) Fodder production (status, constraints and strategies). www.biotecharticles.com/Agriculture-Article/Fodder-ProductionStatus-constraints-strategies-3563.html-constraints-strategies3563.html.

Mangurkar BR (1998) Livestock and environment. Indian Dairyman 50: 41-45

Mathur GN, Sharma R, Choudhary PC (2013) Use of azolla (Azollapinnata) as cattle feed supplement. J Krishi Vigyan 2: 73-75

Meena GS, Dhaka BL, Singh Bacchu, Meena RK, Meena KC (2017) Effect of Azolla as Feed Supplement on Milk Yield in Buffaloes. Int J Curr Microbiol App Sci 6: 3490-3494

Pillai PK, Premantha S, Rajamony S (2002). Azolla- A Sustainable Feed Substitute for Livestock. Leisa Magazine India 3: 15-17

Prabina BJ, Kumar K (2010) Dried azolla as a nutritionally rich cost effective and immuno-modulatory feed supplement for broilers. Asian J Anim Sci 5: 20-22

Rawat Nidhi, Kumari K, Singh F, Gilhare VR (2015). Effect of azollasupplemented feeding on milk production of cattle and production performance of broilers. Appl Biol Res 17: 214- 218

Singh B, Meena GS, Meena KC, Meena RK, Singh B, Indoria D (2017) Effect of a wonder herb azolla on buffaloes milk yield. Int J Curr Microbiol App Sci 6: 1059-1066

Wagner GM (1997) Azolla: A review of its biology and utilization. Bot Rev 63: $1-26$ 